\title{
Human Resource Management (HRM) Practices of the Banking Sector inBangladesh: A Study on Private Commercial Bank
}

\author{
Mohitul Ameen Ahmed Mustafi ${ }^{1 *}$, Tanzia Rahman ${ }^{2}$, Nusrat Jahan ${ }^{3}$ \\ ${ }^{1,3}$ Senior Lecturer, School of Business, Uttara University, Uttara, Dhaka-1230, BANGLADESH \\ ${ }^{2}$ Lecturer, School of Business, Uttara University, Uttara Dhaka-1230, BANGLADESH \\ *E-mail for correspondence: mustafi559@gmail.com
}

DOI: https://doi.org/10.18034/abr.v6i3.39

\begin{abstract}
The purpose of this study is to find out HRM practices on the private commercial banking sector in Bangladesh. The researches want to examine the human resources management practices in the field of banking sector. It evaluates and compares existing human resources management activities of the employee like; job analysis, human resource planning, talent acquisition, training \&development, performance appraisal, compensation, and the industrial relation of nine selective commercial banks. For conducting this research, 100 bank employees are randomly selected from the seven different banks. And out of this 91 employees responses properly; the response rate is 91 percent. The questionnaire consists of individual questions on seven HRM dimensions. The questionnaires were developed by considering five point Liker scale. The collected data were analyzed by applying both descriptive and inferential statistical techniques such as factor analysis and structural equation model (SEM). The SEM results indicated that job analysis, human resource planning, training \& development, compensation, and industrial relation significantly and positively associated with overall human resource practices in private commercial banking sectors in Bangladesh.
\end{abstract}

JEL Classifications: M10; M12; M19

Keywords: Human Resource Management, Private Commercial Bank, SEM

\section{INTRODUCTION}

Human resources are considered the most valuable assets of an organization, but very few organizations are able to utilize this valuable asset. Human resources play a dual role in an organization as operate as factor of production and others operative element. Organization like Banks, and other firms, needs to nurture their human resources in an efficient manner so that profit can be ensured. Banking industries are going through a series of rapid changes because of technological development. Technological advancement has changed the nature of banks demand for employee to better perform their jobs. In an organization People treated as asset when they are equipped with adequate knowledge, skills and competencies (Roknuzzaman, 2007). Human resource management (HRM) is the process which consist of Human resource planning, job analysis, recruitment, selection, orientation, compensation, performance appraisal, training and development, and labor relations (Dessler, 2007). HRM is composed of the policies, practices, and systems that influence employees' behavior, attitude, and performance (Noe, Hollenbeck, Gerhart, and Wright, 2007).This research conducted to find out the implementation of HR practices among private, public and foreign banks.

\section{LITERATURE REVIEW}

In the age of knowledge economy, the most significant resource of the organizations is human resource. Human resource has become requisite for success of any organization (Moyeen and Huq 2001; Schuler 1990; Werther and Davis 1996). There is no doubt that an organization enriched with devoted, motivated, talented, and competent human resource can achieve any kind of challenging goals. HRM practitioner 
discussed about various functions of HRM. Katou (2008) conducted a study to find out the impact of HRM practices on organizational performance especially in the manufacturing sector of Greece. The summery of the survey find out the relationship between HRM practices (resourcing and development, compensation and incentives, involvement and job design) and organizational performance is partially reconciled through HRM outcomes (skills, attitudes, behavior), and it is influenced by business strategies (cost, quality, innovation). The study came to an end with the conclusion that HRM practices are associated with business strategies which will affect organizational performance through HRM outcomes. Iqbal et al (2011) developed a study to contrast the HRM practices of public and private universities of Pakistan among executives. The study found that HRM activities differ in public and private universities. Public universities HRM practices such as job definition, training and development, compensation, team work and employees participation were better than that of private universities. AS per the study performance appraisal practices were better in the private university than public sector universities. Khan (2010) identified that in energetic business environment, there is a need for an approach which achieve better performance, to originate and implement HRM practices. To get a competitive advantage organization need to invest in this aspect. Zulfqar et al. (2012) conducted a study to scrutinize the relationship and nature of relationship between the employee's perceived performance and HRM practices (compensation, performance evaluation, and promotion practices) in the banking sector of Pakistan. The findings of the study found that, the employee perceived performance and HRM practices has the positive and significantly related. Further results indicated that performance evaluation and promotion practices are significant while the compensation practices are insignificant. The current HRM practices (recruitment and selection process, compensation, security of job, growth of career, training and development, management style, job design and responsibilities, reward and motivation and working atmosphere) and its impact on employee's satisfaction in the private banking sector in Bangladesh similar study was conducted by Majumder (2012). As per the study most of the employees are dissatisfied with organizational compensation package followed by reward and maintenance, career advancement, training and development, management approach, and job design and assign responsibilities. Training is a symbol of good management, and a task manager ignore at their dark side. Having qualified employees does not guarantee they will succeed. Instead, they need to know what the management want them to do and how to do it (Afroj, 2012). Hussain and Rehman (2013) analyze the relationship between work effectively for the organization and the HRM practices implemented on employee's intention to stay in the organization. The study found that factors having intense contribution in developing the employees' desire to stay in organization are HRM practices viz-a-viz: person-organization fit, employment security, communication and training and development. HRM practices and employees' retention are positively inter related and such practices enhances employees' retain ability of organizations. Firm performance is continuously influenced by HR practices via employee skills, attitudes or motivation (Park et al.2003). The way HRM practices provide an edge to employee's commitment towards an organization goal in the global competitive market are revealed by Lamba and Choudhary (2013). The study found that organizational commitment are significantly affected by HRM practices such as training \& development, compensation and welfare activities and are associated with superior organizational performance, which help in retention of knowledgeable and skilled employees. It is vital for the high performance movement \& other work reforms effort that focus on employee involvement to recognize the crucial role those job characteristics can play in shaping the performance of employee and ultimately of organization (Cappelli and Regovsky, 1998).

\section{Conceptual Framework}

The objective of this study is to investigate the Implementation of HR Practices in Banking Sector of Bangladesh, on the basis of different functions of human resource management like as job analysis, human resource planning, talent acquisition, training \&development, performance appraisal, compensation, and industrial relation. In the literature, the related studies suggest that the types of factors in path model applications in different banks are job analysis, human resource planning, talent acquisition, training \&development, performance appraisal, compensation, and industrial relation. The theoretical model is presented in figure 1.we will look at the theoretical model for each of the hypotheses in the following bellow. 


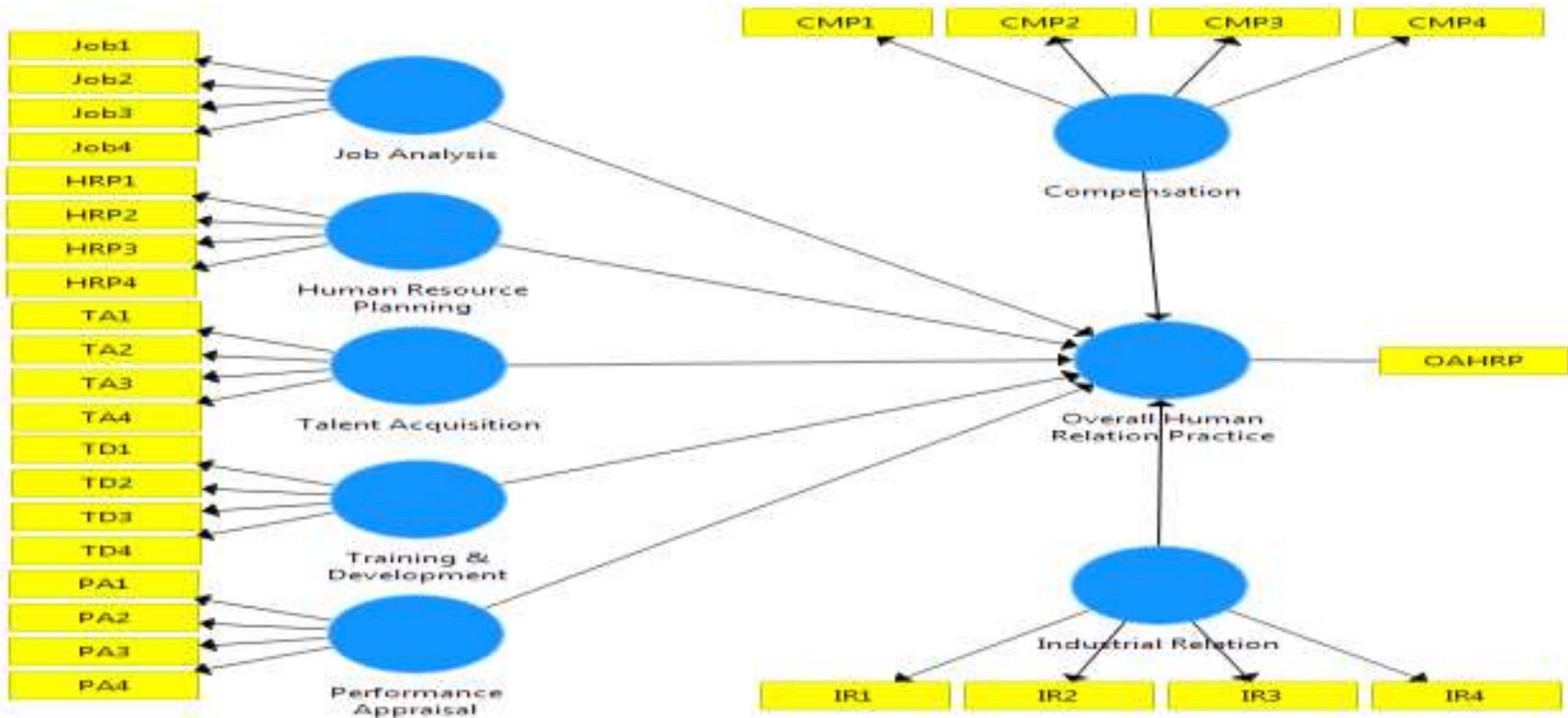

Figure 1: The conceptual frame work of human resource management practies of the private commercial bank limited in bangladesh

\section{RESEARCH OBJECTIVES}

- To determine the influential factors that define the overall human resource management practices in private commercial banks in Bangladesh.

- To investigate the HRM practices given HRM executives of the private commercial banking sector.

\section{HYPOTHESES}

For examining the impact of overall HRM practices on the different banking sector in Bangladesh the following null hypotheses have been framed.

$\mathrm{H}_{01}$ : Job analysis has no significant impact on overall human resource practice in the banking sector.

$\mathrm{H}_{02}$ : Human resource planning has no significant impact on overall human resource practice in the banking sector.

$\mathrm{H}_{03}$ : Talent acquisition has no significant impact on overall human resource practice in the banking sector.

$\mathrm{H}_{04}$ : Training and development has no significant impact on overall human resource practice.

$\mathrm{H}_{05}$ : Performance appraisal has no significant impact on overall human resource practice in the banking sector.

$\mathrm{H}_{06}$ : Compensation has no significant impact on overall human resource practice in the banking sector.

$\mathrm{H}_{07}$ : Industrial relations have no significant impact on overall human resource practice in the banking sector.

\section{METHODOLOGY OF THE STUDY}

Along with literature review, the research is based on survey and observation methods. The survey was conducted in the different office of many commercial banks in Bangladesh, which was chosen purposively. This study has been conducted by seven private commercial banks in Bangladesh. A structured questionnaire was designed to collect primary data by using literature review. In the questionnaire, two statements were completed: one for the above mentioned seven factors of human resource practice dimensions and one for the overall human resource practice of the private commercial banks in Dhaka. Five point Likert scale ranging from 1 (strongly disagree) to 5 (strongly agree) was used to collect data from respondents. Two demographic variables, namely, gender, and age were taken to determine the variability of seven dimensions across those variables. The questionnaire has been sent to 100 respondents who are the bank manager and office executives, regarding different aspects of their present human resource practices but 91 respondents have been selected from there population. The employees were selected by using convenient sampling technique. SPSS software was used for analyzing the demographic information. The exploratory factor analysis and structural equation model adopted to determine the influential factors of overall human resource practices this sector by using Smart PLS software.

Statistical tools used: Both descriptive and inferential statistics were used to analyze the data. Inferential statistics like Factor Analysis (FA) was used to separate the factors related to human resource practices of the bank employees of Bangladesh. Partial Least Square method was also used to identify the significant factors from the factors identified through factor analysis.

Convergent validity: When multiple items are used to measure an individual construct, the item (indicator) convergent validity should be one of the main concerns to the researcher. The measurement model was tested for convergent validity which is the extent to which multiple items to determine the same concepts are in agreement (MacKinnon, 2008). Anderson and Gerbing (1988) stated 
that convergent validity is established if all factor loadings for the items measuring the same construct are statistically significant. According to Hair et al. (1998) convergent validity could be accessed through factor loadings, composite reliability and the average variance extracted. The results of the measurement model (Table 3) show that the loadings for all items exceeded the recommended value of 0.50 (Hair et al. 1998). Composite reliability (CR) values ranged from 0.806 to 0.896 which exceeded the recommended value of 0.70 (Hair et al. 1998).

Discriminant Validity: This study also validated the discriminant validity of the instrument. The discriminant validity represents the extent to which measures of a given construct differ from measures of other constructs in the same model (MacKinnon, 2008). In a PLS, the most important criteria for adequate discriminant validity is that a construct shares more variance with its items than it is shared with other constructs in a given model (Hulland, 1999). It was assessed by examining the correlations between the measures of potentially overlapping constructs. Items loads more strongly on their own constructs in the model, and the square root of the average variance extracted for each construct is greater than the levels of correlations involving the construct (Fornell and Larcker, 1981). As shown in Table 3, the square root of the average variance extracted for each construct is greater than the items on off-diagonal in their corresponding row and column, thus, indicating the adequate discriminant validity. The inter-construct correlations show that each construct shares larger variance values with its own measures than with other measures. In sum, the measurement model demonstrated adequate convergent validity and discriminant validity.

Average variance extracted: All values of the average variance extracted (AVE) that measures the variance captured by the indicators about measurement error were greater than 0.50 to indicate acceptability of the constructs (Fornell and Larcker, 1981; Henseler, Ringle, and Sinkovics, 2009). The table 3 shows that these indicators satisfied the convergent validity of the constructs.

Test of Reliability: To analyze the reliability (internal consistency) of the variables, this study used the Cronbach's alpha coefficient and composite reliability (CR) value. Table 3 shows all Cronbach's alpha values are above 0.60 cutoff values as suggested by Nunnally and Berstein (1994). Standardized Cronbach's alpha formula is given below.

$\alpha=\frac{N \cdot \bar{c}}{\bar{v}+(N-1) \cdot \bar{c}}$

Here, $\mathrm{N}$ is equal to the number of items, c-bar is the average inter-item covariance among the items and v-bar equals the average variance.

The Coefficient of determination: The reliability also finds that the coefficient of determination $\mathrm{R}$ square is 0.883 for the dependent variable i.e., overall HR practices in banking sectors (Table 3). This means that the five independent variables are; job analysis, human resource planning, talent acquisition, training \&development, performance appraisal, compensation, and industrial relation highly explain $88.3 \%$ of the variance in overall HR practices in banking sectors.

\section{DATA ANALYSIS AND FINDINGS Discussion}

Table 1: Demographic Information

\begin{tabular}{|c|c|c|c|c|}
\hline & & Frequency & Percent & $\begin{array}{c}\text { Cumulative } \\
\text { Percent }\end{array}$ \\
\hline \multirow{2}{*}{$\begin{array}{c}\text { Age of the } \\
\text { respondent }\end{array}$} & $\begin{array}{c}25-30 \\
\text { years }\end{array}$ & 41 & 45.1 & 45.1 \\
\cline { 2 - 6 } & $\begin{array}{c}30-35 \\
\text { years }\end{array}$ & 12 & 13.2 & 58.2 \\
\cline { 2 - 6 } & $\begin{array}{c}35 \text { years } \\
\& \text { above }\end{array}$ & 38 & 41.8 & 100.0 \\
\cline { 2 - 6 } & Total & 91 & 100.0 & \\
\hline \multirow{3}{*}{ Gender } & Female & 24 & 26.4 & 26.4 \\
\cline { 2 - 6 } & Male & 67 & 73.6 & 100.0 \\
\cline { 2 - 6 } & Total & 91 & 100.0 & \\
\hline
\end{tabular}

Table 1 provides the frequency distribution of the gender comprised of male and female. A total of 91 respondents in private commercial bank were included in this study, out of which 67 respondents in private commercial bank were male representing $73.6 \%$ of the total population and remaining 24 respondents were female representing 26.4 $\%$ of the total population. Age of 91 respondents in private commercial bank, 41 respondents who were having age $25-30$ years representing $45.1 \%$ of the total population and only 12 respondents were heaving age 30-35 years representing $13.2 \%$ of the total population.

\section{EXPLORATORY FACTOR ANALYSIS}

EFA is a widely utilized and broadly applied statistical technique in social science. A total 90 usable survey responses were analyzed in this section. The factor analysis technique has been applied to examine the relationship between different factors in HR practice. The seven factors that have found from rotated factor matrix, have been discussed in the following paragraph.

Factor-1 (Job Analysis): This includes four variables like clear job responsibility, frequent supervision, independency, and availability of supervisor which are the principal factors. So, it provides a basis for conceptualization of a dimension which may be identified as job analysis factor.

Factor-2 (Human Resource Planning): This includes four variables like HRIS, implementation of HRP, Identification of HR needs, usage of succession planning which are the principal factors. So, it provides a basis for conceptualization of a dimension which may be identified as human resource planning factor. 
Factor-3 (Talent Acquisition): This includes four variables like selection of quality employees, usages of competence model, scope of improvement in current hiring process, job specification which is the principal factors. So, it provides a basis for conceptualization of a dimension which may be identified as talent acquisition factor.

Factor-4 (Training and Development): This includes four variables like arrangement of training program, identification of training needs, defining training objectives, and relevancy of content of training which are the principal factors. So, it provides a basis for conceptualization of a dimension which may be identified as training \& development factor.

Factor-5 (Performance Appraisal): This includes four variables like regularity of performance appraisal, an output of appraisal, communication of feedback, the usefulness of feedback are the principal factors. So, it provides a basis for conceptualization of a dimension which can be identified as performance appraisal factor.

Factor-6 (Compensation): This includes four variables like relevance of compensation package to market, disbursement of salary within in time, the relevance salary with the qualification which is the principal factors. So, it provides a basis for the conceptualization of a dimension which may be identified as factor of compensation.

Factor-7 (Industrial Relation): This includes four variables like collective bargaining, solving problem mutually, positive working environment, addressing labor laws which are the principal factors. So, it provides a basis for the conceptualization of a dimension which may be identified as factor of industrial relation.

Table 2: Results Summary for Reflective Outer Model

\begin{tabular}{|c|c|c|c|c|c|c|c|c|}
\hline $\begin{array}{l}\text { Latent } \\
\text { Variable }\end{array}$ & Indicators & $\begin{array}{c}\text { Factor } \\
\text { Loading }\end{array}$ & T-value & $\begin{array}{l}\text { Indicator } \\
\text { Reliability }\end{array}$ & $\begin{array}{l}\text { Composite } \\
\text { Reliability }\end{array}$ & $\begin{array}{c}\text { Average } \\
\text { Variance } \\
\text { Extracted (AVE) }\end{array}$ & $\begin{array}{c}\text { Discriminant } \\
\text { Validity }\end{array}$ & $\begin{array}{c}\text { Cronbach's } \\
\text { Alpha }\end{array}$ \\
\hline \multirow{3}{*}{$\begin{array}{l}\text { Job } \\
\text { Analysis }\end{array}$} & Job1 & 0.763 & 13.497 & 0.87 & \multirow{3}{*}{0.837} & \multirow{3}{*}{0.632} & \multirow{3}{*}{0.795} & \multirow{3}{*}{0.709} \\
\hline & Job2 & 0.795 & 11.665 & 0.89 & & & & \\
\hline & Job4 & 0.825 & 14.156 & 0.91 & & & & \\
\hline \multirow{3}{*}{$\begin{array}{l}\text { Human } \\
\text { Resource } \\
\text { Planning }\end{array}$} & HRP1 & 0.809 & 14.283 & 0.90 & \multirow{3}{*}{0.871} & \multirow{3}{*}{0.692} & \multirow{3}{*}{0.833} & \multirow{3}{*}{0.779} \\
\hline & HRP2 & 0.87 & 23.651 & 0.93 & & & & \\
\hline & HRP3 & 0.816 & 19.364 & 0.90 & & & & \\
\hline \multirow{4}{*}{$\begin{array}{l}\text { Talent } \\
\text { acquisition }\end{array}$} & TA1 & 0.728 & 8.038 & 0.85 & \multirow{4}{*}{0.857} & \multirow{4}{*}{0.601} & \multirow{4}{*}{0.775} & \multirow{4}{*}{0.780} \\
\hline & TA2 & 0.773 & 12.572 & 0.88 & & & & \\
\hline & TA3 & 0.749 & 10.802 & 0.87 & & & & \\
\hline & TA4 & 0.846 & 33.779 & 0.92 & & & & \\
\hline \multirow{3}{*}{$\begin{array}{l}\text { Training and } \\
\text { development }\end{array}$} & TD1 & 0.854 & 25.593 & 0.92 & \multirow{3}{*}{0.896} & \multirow{3}{*}{0.742} & \multirow{3}{*}{0.862} & \multirow{3}{*}{0.827} \\
\hline & TD2 & 0.862 & 16.364 & 0.93 & & & & \\
\hline & TD3 & 0.869 & 28.701 & 0.93 & & & & \\
\hline \multirow{3}{*}{$\begin{array}{l}\text { Performance } \\
\text { Appraisal }\end{array}$} & PA2 & 0.753 & 13.784 & 0.87 & \multirow{3}{*}{0.879} & \multirow{3}{*}{0.710} & \multirow{3}{*}{0.843} & \multirow{3}{*}{0.795} \\
\hline & PA3 & 0.887 & 31.261 & 0.94 & & & & \\
\hline & PA4 & 0.88 & 28.60 & 0.94 & & & & \\
\hline \multirow[t]{3}{*}{ Compensation } & CMP1 & 0.727 & 9.444 & 0.85 & \multirow{3}{*}{0.832} & \multirow{3}{*}{0.625} & \multirow{3}{*}{0.792} & \multirow{3}{*}{0.699} \\
\hline & CMP3 & 0.772 & 10.231 & 0.88 & & & & \\
\hline & CMP4 & 0.866 & 29.647 & 0.93 & & & & \\
\hline \multirow{3}{*}{$\begin{array}{l}\text { Industrial } \\
\text { relation }\end{array}$} & IR1 & 0.744 & 8.347 & 0.86 & \multirow{3}{*}{0.806} & \multirow{3}{*}{0.581} & & \\
\hline & IR2 & 0.749 & 9.836 & 0.87 & & & 0.762 & 0.639 \\
\hline & IR3 & 0.793 & 16.875 & 0.89 & & & & \\
\hline
\end{tabular}

Note: AVE >0.50 (Fornell\&Larcker, 1981); Henseler, Ringle, \&Sinkovics, 2009), Composite Reliability >0.70 (Hair et al. 1998), Cronbach's alpha $>=0.60$, (Nunnally and Berstein (1994))

From table 2 shows that all of the T-Statistic are larger than 1.96 at $5 \%$ level of significance, we can say that the outer model loadings are highly significant. So, our SEM model is accepted for above evidence in this study. Generally, A global fit measure (GOF) was conducted for path modeling; it is defined as the geometric mean of average communality and average $R^{2}$ (especially endogenous variables) (Chin, 2010) (see the formula). In this study,
GOF value was $0.76\left(R^{2}=0.883\right.$, average $\mathrm{AVE}=0.65$ for overall human resource practice). So, the value of GOF exceeded the largest cut-off value (0.36), and it was indicated that the proposed model of this study had better explaining power than that based on the recommended value of $\mathrm{GOF}_{\text {small }}=0.1, \mathrm{GOF}_{\text {medium }}=0.25$, and $\mathrm{GOF}_{\text {large }}=0.36$ (Akter et al., 2011).

$\mathrm{GOF}=\sqrt{A V E \times R^{2}}$ 
Path Diagram of Private commercial bank

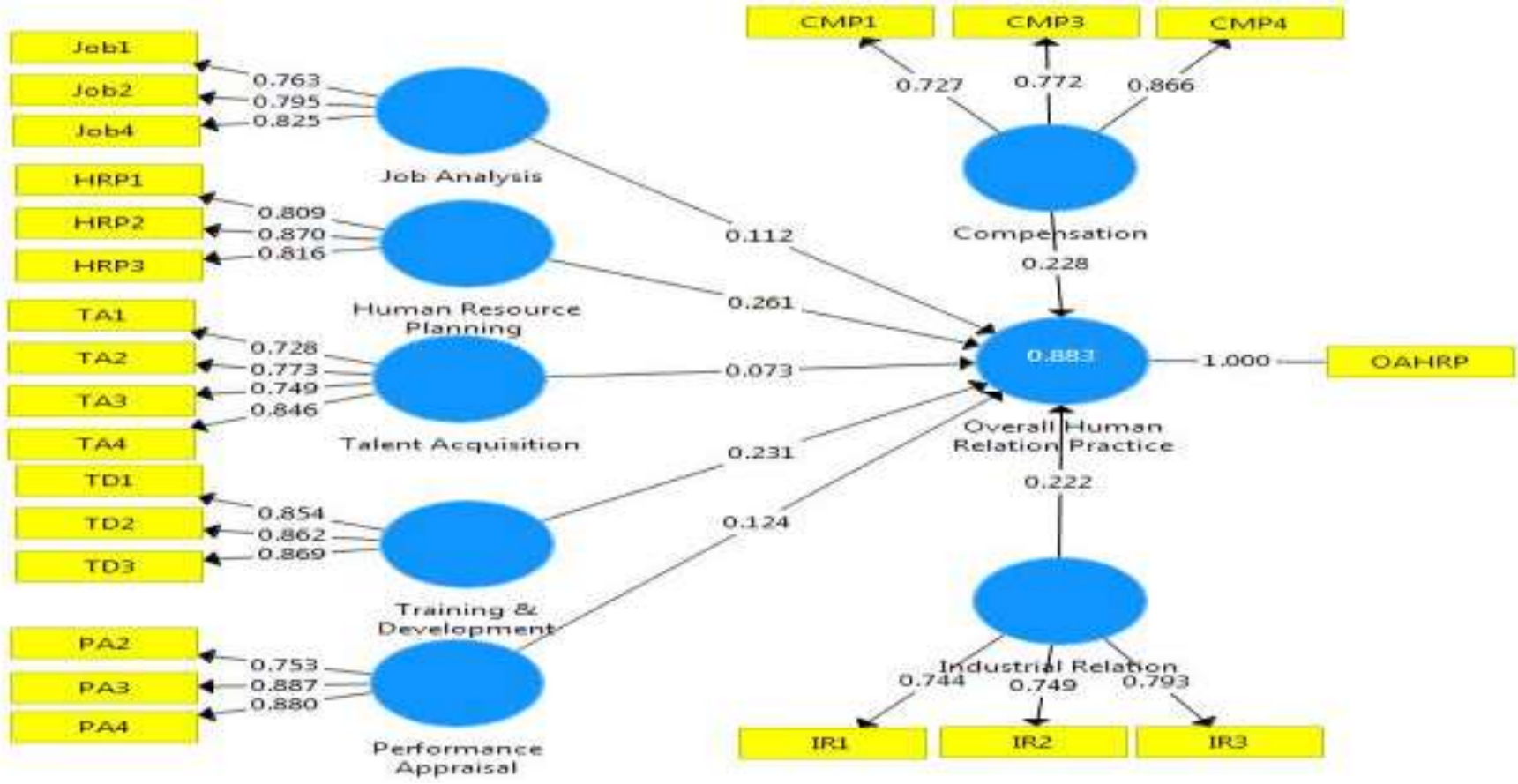

Figure 2 Relative Importance of the Human Resource Practice Factors and their Relationship with Overall Human Resource Practice of employees of Private Commercial Banking Sectors.

Table 3: Summary Results of the Model Constructs

\begin{tabular}{|c|c|c|c|c|c|c|}
\hline & $\begin{array}{l}\text { Original } \\
\text { Sample }\end{array}$ & $\begin{array}{c}\text { Sample } \\
\text { Mean }\end{array}$ & $\begin{array}{c}\text { Standard } \\
\text { Deviatio } \\
n\end{array}$ & $\begin{array}{c}\mathrm{T} \\
\text { Statistic }\end{array}$ & $\begin{array}{c}\mathrm{P} \\
\text { Values }\end{array}$ & Supported \\
\hline Job Analysis ->Overall HR Practice & 0.112 & 0.115 & 0.053 & $2.100^{*}$ & 0.036 & YES \\
\hline $\begin{array}{c}\text { Human Resource Planning -> Overall HR } \\
\text { Practice }\end{array}$ & 0.261 & 0.260 & 0.057 & $4.590^{* * *}$ & 0.000 & YES \\
\hline Talent Acquisition ->Overall HR Practice & 0.073 & 0.073 & 0.057 & 1.274 & 0.203 & $\mathrm{NO}$ \\
\hline $\begin{array}{c}\text { Training \& Development }->\text { Overall HR } \\
\text { Practice }\end{array}$ & 0.231 & 0.229 & 0.042 & $5.449^{* * *}$ & 0.000 & YES \\
\hline $\begin{array}{l}\text { Performance Appraisal ->Overall HR } \\
\text { Practice }\end{array}$ & 0.124 & 0.126 & 0.066 & 1.888 & 0.060 & $\mathrm{NO}$ \\
\hline Compensation_->Overall HR Practice & 0.228 & 0.221 & 0.050 & $4.597^{* * *}$ & 0.000 & YES \\
\hline Industrial Relation ->Overall HR Practice & 0.222 & 0.224 & 0.060 & $3.714^{* * *}$ & 0.000 & YES \\
\hline R Square & \multicolumn{6}{|c|}{0.883} \\
\hline R Square Adjusted & \multicolumn{6}{|c|}{0.873} \\
\hline
\end{tabular}

*** Path coefficient is highly significant at the 0.01 level (2-tailed). * Path coefficient is statistically significant at the 0.05 level (2-tailed).

\section{Measurement of the Structural Model}

Once all the constructs in the measurement model were validated, structural model has to be tested. The bootstrapping technique was conducted to generate $t$ value for each of the hypothesized relationship and the potential impact of covariates. The researcher conducted the bootstrapping approach with 500 samples, with 0 cases per sample to test the path coefficient $(\beta)$ and proposed hypotheses. Table 5 and Figure 1 presented the results of the hypotheses testing. The findings revealed that compensation $(\beta=0.228 ; t=4.597$, human resource planning $(\beta=0.261, t=4.59)$, industrial relation $(\beta=0.222$; $t=3.714)$, job analysis $(\beta=0.112 ; t=2.10)$, performance appraisal $(\beta=0.124, t=1.888)$, talent acquisition $(\beta=0.073$, $t=1.274)$ and training \& development $(\beta=0.231, t=$ 5.449)were found to be related to overall human relation practice, with the evidence that these seven formulated hypotheses exceeded the recommended value, 1.96 ( $<$ $0.05)$, hence, $\mathrm{H}_{1}, \mathrm{H}_{2}, \mathrm{H}_{3}, \mathrm{H}_{4}$, and $\mathrm{H}_{5}$, were supported. The $R^{2}$ value of HR Practices construct is 0.883 suggesting that $88.3 \%$ of the variance in HR practice was explained by Job analysis, HRP, Talent Acquisition, Training and Development, Performance Appraisal, Compensation and Industrial relation. 


\section{HyPOTHESES TESTING}

The hypothesis testing was carried out by examining the path coefficients (beta) between latent constructs and their significance. To justify the significance of the path coefficients the bootstrapping method was used with a resampling of 500 (e.g., Bradley et al., 2012). The $R^{2}$ value of endogenous latent construct illustrates the predictive relevance of the model. Table 03 presents the results and hypothesis testing. The findings show that the hypotheses $\mathrm{H}_{02}, \mathrm{H}_{04}, \mathrm{H}_{06}$, and $\mathrm{H}_{07}$ werehighly significant at $1 \%$ level of significance because the value of $t$ is higher than 2.57 , but $\mathrm{H}_{01}$ was statistically significant at $5 \%$ level of significance because the value of $\mathrm{t}$ is higher than 1.96.

Table 4: Outcome of hypothesized relationships

\begin{tabular}{|l|l|l|}
\hline $\mathrm{H}_{01}$ & $\begin{array}{l}\text { Job analysis has no significant impact } \\
\text { on overall human resource practice } \\
\text { in the banking sector. }\end{array}$ & $\begin{array}{l}\text { Rejected } \\
\text { Rejected }\end{array}$ \\
\hline $\mathrm{H}_{02}$ & $\begin{array}{l}\text { Human resource planning has no } \\
\text { significant impact on overall human } \\
\text { resource practice in banking sector. }\end{array}$ & Rejected \\
\hline $\mathrm{H}_{03}$ & $\begin{array}{l}\text { Talent acquisition has no significant } \\
\text { impact on overall human resource } \\
\text { practice in the banking sector. }\end{array}$ & Accepted \\
\hline $\mathrm{H}_{04}$ & $\begin{array}{l}\text { Training and development has no } \\
\text { significant impact on overall human } \\
\text { resource practice. }\end{array}$ & Rejected \\
\hline $\mathrm{H}_{05}$ & $\begin{array}{l}\text { Performance appraisal has no } \\
\text { significant impact on overall human } \\
\text { resource practice in the banking } \\
\text { sector. }\end{array}$ & Accepted \\
\hline $\mathrm{H}_{06}$ & $\begin{array}{l}\text { Compensation has no significant } \\
\text { impact on overall human resource } \\
\text { practice in banking sector. }\end{array}$ & Rejected \\
\hline $\mathrm{H}_{07}$ & $\begin{array}{l}\text { Industrial relation has no significant } \\
\text { impact on overall human resource } \\
\text { practice in the banking sector. }\end{array}$ & Rejected \\
\hline
\end{tabular}

\section{Discussion AND CONCLUSION}

The main aim of this study was to focus on the overall HR practice. We tried to compose a conceptual model that would better predict and explain HR practice in banking sectors. The model was evaluated based on data collected from 91 respondents. Our model seems to have better power to explain the respondents' attitude towards Job analysis, HRP, Talent Acquisition, Training and development, Performance Appraisal, Compensation and Industrial relation. The HR practice accounted for 88.9 percent of the variance explained.

\section{Job Analysis and Overall Human Relation Practice $\left(\mathrm{H}_{1}\right)$}

One of the factors to be considered to have a positive impression on any bank is job analysis. Job analysis is a component of HR function explaining whether job responsibilities are clearly defined or not, frequent supervision of work, and availability of the supervisor in the banking sector of Bangladesh. In our study; we found that job analysis to overall human relation practice is statistically significant at 5\% level of significance. So, the null hypothesis $\left(\mathrm{H}_{1}\right)$ is rejected. This means that job analysis is influential factor to the overall human resource practice in private banking sector in Bangladesh.

\section{Human Resource Planning to Overall Human Relation Practice $\left(\mathrm{H}_{2}\right)$}

The factors that are covered under this part are implementation of HRIS, whether HR planning is fully addressed or not, and identification of HR needs. So, it provides a basis for conceptualization of a dimension which may be identified as human resource planning factor. In our study; we found that human resource planning to overall human relation practice is highly significant at $1 \%$ level of significance. So, the null hypothesis $\left(\mathrm{H}_{2}\right)$ is rejected. This means that human resource planning has influenced on the overall human resource practice in the private banking sector in Bangladesh.

\section{Talent Acquisition and Overall Human Relation Practice $\left(\mathrm{H}_{3}\right)$}

Talent acquisition means finding and attracting qualified employees for against a specific position.HR plays a vital role in an organization. Basically $H R$ provide a competitive advantage to the organization.HR is the only assets which never be duplicated. The factors that are covered under Talent Acquisition: selection of quality employees, whether they are using competence model or not, IS there any scope of improvement in current hiring process and job specification. In our study; we found that talent acquisition to overall human relation practice is not significant at 5\% level of significance. So, the null hypothesis $\left(\mathrm{H}_{2}\right)$ is not rejected. This means that talent acquisition is not influential factor to the overall human resource practice in private banking sector in Bangladesh.

\section{Training and Development and Overall Human Relation Practice $\left(\mathrm{H}_{4}\right)$}

Training and development is related to acquiring skill and knowledge about a specific job. It also makes easy to progress quality of work. Training and development are related to speed and service capabilities to customer, understanding the needs and requirements of the customer, ensuring easy operation, providing individual attention by the staff, and also giving attention to the problem and customers' satisfaction. The factors that are covered under Training \& Development are: arrangement of training program, identification of training needs, defining training objectives, and relevancy of content of training program. In our study; we found that training \& development to overall human relation practice is highly significant at $1 \%$ level of significance. So, the null hypothesis $\left(\mathrm{H}_{2}\right)$ is rejected. This means that training \& development is the influential factor to the overall human resource practice in the private banking sector in Bangladesh. 


\section{Performance Appraisal and Overall Human Relation Practice $\left(\mathrm{H}_{5}\right)$}

Performance appraisal is related to let employees know how they are doing performance appraisal is interrupted process which compares an individual employee's job performance and productivity against a standard. Other aspects of employees' appraisal are related to accomplishments, potential for future development, strengths and weaknesses etc. The factors that are covered under Performance appraisal are regularity of performance appraisal, output of appraisal, communication of feedback, usefulness of feedback are the principal factors. In our study; we found that performance appraisal to overall human relation practice is not significant at $5 \%$ level of significance. So, the null hypothesis $\left(\mathrm{H}_{2}\right)$ is not rejected. This means that performance appraisal is not the influential factor to the overall human resource practice in the private banking sector in Bangladesh.

\section{Compensation to Overall Human Relation Practice $\left(\mathrm{H}_{6}\right)$}

Employee compensation is related to an amount that employee can expect to receive from the organization. There are different types of compensation packages that an employer will suggest employees. The factors that are covered under compensation are relevance of compensation package to market, disbursement of salary within in time, relevance salary with qualification, etc. In our study; we found that compensation to overall human relation practice is highly significant at $1 \%$ level of significance. So, the null hypothesis $\left(\mathrm{H}_{1}\right)$ is rejected. This means that compensation has influenced on overall human resource practice in the private banking sector in Bangladesh.

\section{Industrial Relation and Overall Human Relation Practice $\left(\mathrm{H}_{7}\right)$}

Industrial relation is a practice that denotes the relations among employers, workers, and other organizations. Individual relations concern employers and workers at their places of work, collective relations between employers and trade unions. "Industrial relation is fearful with the systems and procedures used by unions and employers to decide the reward for the attempt and other conditions of employment, to protect the interests of the employed and their employers and to regulate the ways in which employers treat their employees." (Armstrong)The factors that are covered under Industrial relation are like collective bargaining, solving problem mutually, positive working environment, addressing labor laws which are the principal factors etc. In our study; we have found that industrial relation to overall human relation practice is highly significant at $1 \%$ level of significance. So, the null hypothesis $\left(\mathrm{H}_{7}\right)$ is rejected. This means that industrial relation is an influential factor to the overall human resource practice in the private banking sector in Bangladesh.

\section{ReCOMMENDATION}

The present study is an attempt to find out and analyze the Implementation of HR practices in banking sector of Bangladesh. Dessler (2007) found that human resource management (HRM) refers to the policies and practices involved in human resource planning, job analysis, recruitment, selection, orientation, compensation, performance appraisal, training and development, and labor relations. In the present study, structural equation model (SEM) identified that the HRM practices mainly Job Analysis, Human Resource Planning, Training and Development, Compensation, and Industrial Relation have the significant impact on overall HR practices. On the other hand performance appraisal and talent acquisition have no significant impact on overall HR practices in the banking sector of Bangladesh. The study recommends that Banks have to emphasize on performance appraisal process and employees should be rewarded based on their appraisal output. Other practice like talent acquisition has to be given importance.

In this context, the following policy actions may be considered worthwhile.

- Organizations should carefully conduct recruitment and selection process.

- Organizations should introduce proper performance appraisal systems. Promotion practices were found to be insignificantly associated with employee performance. Mostly promotions are done without following any criteria and merit. Promotional activities are unclear and vague. Results of such type of activities are often kept hidden.

- Organizations should induce employees to perform well. This can be achieved by providing reward, motivations, and other benefits etc.

- Organizations should provide unbiased promotion. That is promotion should be provided based on the qualification of employees and /or experience.

\section{REFERENCES}

Afroj, S. (2012). Ongoing Corporate Human Resource Management Practice in Banking sector of Bangladesh. Global Journal of Management and Business Research, 12(2).

Akter, S., D'Ambra, J., \& Ray, P. (2011). Trustworthiness in mHealth information services: an assessment of a hierarchical model with mediating and moderating effects using partial least squares (PLS). Journal of the American Society for Information Science and Technology, 62(1), 100-116.

Aleem, M., Bowra, Z. A., Hamed, W., \& Khan, A. H. (2012). An empirical investigation of human resource practices: A study of autonomous medical institution employees in Punjab, Pakistan. African Journal of Business Management, 6(21), 6390.

Anderson, J. C., \& Gerbing, D. W. (1988). Structural equation modeling in practice: A review and recommended two-step approach. Psychological bulletin, 103(3), 411. 
Bowra, Z. A., Sharif, B., Saeed, A., \& Niazi, M. K. (2012). Impact of human resource practices on employee perceived performance in banking sector of Pakistan. African Journal of Business Management, 6(1), 323.

Cappelli, P., \&Rogovsky, N. (1998). Employee Involvement and Organizational Citizenship: Implications for Labor Law Reform and "Lean Production\# x201D. Industrial \& Labor Relations Review, 51(4), 633-653.

Chand, M., \&Katou, A. A. (2007). The impact of HRM practices on organisational performance in the Indian hotel industry. Employee Relations, 29(6), 576-594.

Chin, W. W. (2010). How to write up and report PLS analyses. In Handbook of partial least squares (pp. 655-690). Springer Berlin Heidelberg.

Cronbach, L. J. (1951). Coefficient alpha and the internal structure of tests. psychometrika, 16(3), 297-334.

Dessler, G. (2007). Human Resource Management. (11th ed.). New Jersey: Prentice Hall.

Efron, B. (2012). The estimation of prediction error. Journal of the American Statistical Association.

Fornell, C., \& Larcker, D. F. (1981). Evaluating structural equation models with unobservable variables and measurement error. Journal of marketing research, 39-50.

Gerbing, D. W., \& Anderson, J. C. (1988). An updated paradigm for scale development incorporating unidimensionality and its assessment. Journal of marketing research, 186-192.

Hair, J. F., \& Anderson, R. E. RL Tatham in WC Black (1998). Multivariate Data Analysis with Readings,.

Henseler, J., Ringle, C. M., \&Sinkovics, R. R. (2009). The use of partial least squares path modeling in international marketing. Advances in international marketing, 20(1), 277-319.

Hulland, J., \& Richard Ivey School of Business. (1999). Use of partial least squares (PLS) in strategic management research: A review of four recent studies. Strategic management journal, 20(2), 195-204.

Hussain, T., \& Rehman, S. S. (2013). Do Human Resource Management Practices Inspire Employees' Retention?Research Journal of Applied Sciences, Engineering and Technology, 6(19), 3625-3633.

Iqbal, M. Z., Arif, M. I., \& Abbas, F. (2011). HRM practices in public and private universities of Pakistan: A comparative study. International Education Studies, 4(4), 215.
Iqbal, M. Z., Arif, M. I., \& Abbas, F. (2011). HRM practices in public and private universities of Pakistan: A comparative study. International Education Studies, 4(4), 215.

Katou, A. A. (2008). Measuring the impact of HRM on organizational performance. Journal of Industrial Engineering and Management, 1(2), 119-142.

Khan, M. A. (2010). Effects of human resource management practices on organizational performance-an empirical study of oil and gas industry in Pakistan. European Journal of Economics, Finance and Administrative Sciences, 24(157-174), 6.

Lamba, S., \&Choudhary, N. (2013). Impact of HRM practices on organizational commitment of employees. International Journal of Advancements in Research \& Technology, 2(4), 407-423.

MacKinnon, D. P. (2008). Introduction to statistical mediation analysis. Routledge.

Majumder, M. T. H. (2012). Human resource management practices and employees' satisfaction towards private banking sector in Bangladesh. International Review of Management and Marketing, 2(1), 52.

Moyeen, A. F. M. A., \& Huq, A. (2001). Human resource management practices in business enterprises in Bangladesh. Journal of Business Studies, 22(2), 263-270.

Noe, R. (2007). Hollenbeck JR, Gerhart, B. A., and Wright, PM. Human Resource Management (2nd Ed.). Boston: McGraw-Hill Irwin.

Nunally, J. C., \& Bernstein, I. H. (1994). Psychometric theory, 3rd. New York: Mcgraw-Hill.

Park, H. J., Mitsuhashi, H., Fey, C. F., \&Björkman, I. (2003). The effect of human resource management practices on Japanese MNC subsidiary performance: a partial mediating model. The International Journal of Human Resource Management, 14(8), 1391-1406.

Roknuzzaman, M. (2007). Status of human resource management in public university libraries in Bangladesh. The International Information \& Library Review, 39(1), 52-61.

Schuler, R. S. (1990). Repositioning the human resource function: transformation or demise?.The Executive, 4(3), 49-60.

Talukder, M. F. H., Hossain, M. Y., \& Hossain, M. N. (2014). HRM practice in commercial banks: A case study of Bangladesh. IOSR Journal of Business and Management 16: 29, 36.

William, B., Werther, J., \& Davis, K. (1996). Human resource and personnel management. City: McGraw-Hill Inc, 316-317. 
Online Archive: https://abc.us.org/ojs/index.php/abr/issue/archive

\section{S) Worldcat Google scholar abcGATE $\gg$ BASE}

